\title{
THE DECREE OF THE CENTRAL COMMITTEE OF THE ALL-UNION COMMUNIST PARTY OF BOLSHEVIKS IN AUGUST 1944 AND THE TATAR INTELLIGENTSIA
}

\author{
A.G. Gallyamova ${ }^{l a}$, A.Sh. Kabirova ${ }^{1 b}$, I.I. Khanipova ${ }^{1 c}$ \\ ${ }^{1}$ Marjani Institute of History of Tatarstan Academy of Sciences \\ Kazan, Russian Federation

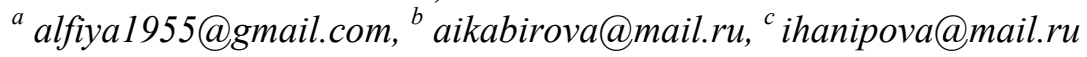

\begin{abstract}
Research objectives: To analyze the reasons for the promulgation of the Decree of the Central Committee of the All-Union Communist Party of Bolsheviks of August 9, 1944, "On the Status and Measures of Improving Mass-Political and Ideological Work of the Tatar Party Organization", and determine its impact on the activities of the Tatar creative and humanitarian intelligentsia in the second half of the 1940s and early 1950s.

Research materials: Documentary sources from federal and regional archives, along with specialized studies.

Results and novelty of the research: The authors believe that the adoption of the 1944 Decree should be considered in the context of changes in the general political situation in the country associated with the strengthening of the dictatorship of the state and the destruction of liberal ideological trends at the end of World War II. The promotion of the national spirit, necessary for the survival of the state in military conditions, lost its relevance and gave way to great-power sentiments. The Decree was used as a "whip" against the national intelligentsia, but it did not stop the development of humanitarian thought. Many creative figures recognized the ideological framework only externally, while in reality, they often went far beyond it and continued to work actively in the study of ethnic history and culture.
\end{abstract}

Keywords: national policy, Tatar Autonomous Soviet Socialist Republic, Soviet culture, history of the Tatars, Golden Horde, censor, Decree of the Central Committee of the All-Union Communist Party of Bolsheviks on August 9, 1944

For citation: Gallyamova A.G., Kabirova A.Sh., Khanipova I.I. The Decree of the Central Committee of the All-Union Communist Party of Bolsheviks in August 1944 and the Tatar Intelligentsia. Zolotoordynskoe obozrenie=Golden Horde Review. 2020, vol. 8, no. 1, pp. 185-199. DOI: 10.22378/2313-6197.2020-8-1.185-199

The adherence to communist ideology was the main indicator of the political trustworthiness of man in Soviet society. The role of the guides of the dominant ideological paradigm was assigned to the intelligentsia whose activities were strictly regulated by the authorities. Scholars, writers, artists were supposed to participate in the formation and education of the so-called "new man". In this context, in the 1930s in Tatarstan, as throughout the country, works appeared glorifying the revolution, the greatness of the new system, and labor achievements in the name of the triumph of socialism.

The years of the Great Patriotic War became a time when the threat looming over the state forced it to make ideological concessions in the spiritual sphere. 
However, this did not last long. The situation radically changed in accordance with the situation on the war fronts, which moved away from the territory of the USSR. The decree "On the Status and Measures of Improving Mass-Political and Ideological Work of the Tatar Party Organization", promulgated by the Central Committee of the All-Union Communist Party of Bolsheviks on August 9, 1944, testified to this in all evidence. Attempts by the country's leadership to regulate the activities of the Tatar humanitarian intelligentsia intensified many times in the postwar years. The article is aimed at both analyzing the reasons for the Decree's promulgation and determining its impact on the activities of the Tatar creative and humanitarian intelligentsia in the second half of the 1940s and early 1950s.

A historiographic review of specialized articles regarding the topic reveals increased interest among researchers. I.L. Izmailov's [13; 14] and D.M. Iskhakov's $[16 ; 17 ; 18]$ articles contain a thorough and conceptual presentation of the issue under consideration. In the period of the collapsed communist monopoly on the interpretation of history, they were the first to thoroughly describe the situation in the Tatar humanities. It is especially valuable that I.L. Izmailov [13] published archival materials that provide the reader with the opportunity for further independent reflection. Tatarstan humanitarians pay serious attention to the discussion of the relations between the authorities and the Tatar creative community in the period of late Stalinism. A.G. Gallyamova discussed the processes of interaction between the political and intellectual elite of the Tatar Autonomous Soviet Socialist Republic in the 1950s and 1960s [7; 8; 9]. She introduced into scholarly circulation and analyzed a large set of documents from the republican and central archives detailing the cultural policy and its implementation in the Tatar ASSR until perestroika. An attempt in 1958 to disavow the assessments of the history and cultural heritage of the Tatar people promulgated fourteen years earlier is of particular interest in the context of the article [8, p. 243]. R.B. Khaplekhamitov, in turn, described the specifics of the sociocultural situation and the position of the Tatar intelligentsia in the second half of the 1940s and 1950s [37]. D. Galiullina presented a discussion of the controversial stages in the history of the Tatar people in the university environment in the second half of the 1940s [6]. Various aspects of the issue were considered in the works of B.F. Sultanbekov [33], I.R. Tagirov [34], A.Sh. Kabirova [19], D.A. Pinaeva [28]. At the same time, despite a number of publications, the formation of ideological principles in the field of state nationalcultural policy in the Tatar ASSR, their influence on the activities of the Tatar intelligentsia and the development of national culture in the post-war decades are still not fully understood. This is the reason why the authors turned to this topic.

The realities of the initial period of the war connected with the catastrophic situation on the fronts showed that the ideological basis of the 1930s was not enough to induce Soviet people to mobilize internally for the struggle and readiness to die for the country. Therefore, the authorities returned to the primordial presocialist values, traditionally used to raise the military spirit and strengthen universal patriotism. Instead of class bonds of the consolidation of society, they resorted to propagating examples of military prowess from Russian history, legalizing the persecuted religious feelings, shifting the focus of the formation of public consciousness from the principles of abstract "proletarian internationalism" to national values. 
The content of the propaganda work changed due to new ideological imperatives: many events of the pre-October history of Russia began to be evaluated positively, the number of lectures on the heroic-patriotic topic increased. In the first nine months of the war, twenty-one thousand lectures with the participation of about two million people were delivered in Tatarstan only in rural areas. Militaryhistorical subjects prevailed: "The Patriotic War of 1812", "Civil War", "The rout of the Entente", etc. Republican newspapers "Krasnaya Tataria" and "Kyzyl Tatarstan" solved propaganda tasks. Special display cases for central and local newspapers and messages of the Soviet Information Bureau were installed in crowded places due to the decrease in the number of periodicals because of the difficulties of the war period. The Tatar book publishing house significantly increased the volume of output and published, during the war years, 670 books and brochures of a political and defense nature in Russian and Tatar languages with a circulation of more than 10 million copies ${ }^{1}$.

The so-called "religious revival" became an effective tool for influencing the masses. The decision to stop all anti-religious propaganda in the country was made at the state level. For the first time after the devastating actions of previous years, people were allowed to visit churches and mosques and conduct the necessary rituals. They began to celebrate Kurban Bayram and Easter. Pilgrimage to holy places intensified. Among the Muslims of the Tatar ASSR, these places were Bolghar in the Kuibyshev (nowadays Spassky) district, holy spring key in the Bilyar district of the Republic, grave of the "Seven Saints Young Ladies" in the Tatar cemetery in Kazan.

The permission of the authorities to conduct religious services and ceremonies revealed the need of the population of Tatarstan in religious buildings that ceased their activities in the midst of atheistic campaigns. By 1941, the bulk of religious buildings in the republic was closed [see 12, p. 63; 20, p. 229-334, 338-343]. Believers dared to resume the struggle for their return taking advantage of ideological concessions. For example, archival funds preserved the appeals of Christians in the village of Verkhniy Aktash (Aktash district), the village of Maloe Podberezye (Podberezinsky district), the village of Arbuzov-Baran (Bilyar district), etc., addressed to F.F. Gorbachev, Plenipotentiary of the Council for Russian Orthodox Church Affairs in Tatar ASSR, requesting the opening of churches ${ }^{2}$. Muslims addressed their applications to Kh.S. Bagaev, Plenipotentiary of the Council for Religious Cults in Tatarstan. In 1945, Bagaev received 30 applications for the opening of mosques from 26 districts of the Republic, including from residents of the village of Staroe Alparovo (Alkeevsky district), the village of Ibraikino (Aksubaevsky district), etc $^{3}$. In the same year, part of the submitted applications was granted ${ }^{4}$.

The permission to perform a Hajj to a group of believers of 17 people (with two people from the Tatar ASSR) was a very significant event for Muslims of the country. In 1943, in addition to the current Central Spiritual Administration of

\footnotetext{
${ }^{1}$ State Archive of the Republic of Tatarstan. Fund P-15. Inventory 5. Case 200a. Folios 69-70.

${ }^{2}$ State Archive of the Republic of Tatarstan. Fund R-873. Inventory 1. Case 8. Folios 5658; Case 9. Folio 109; Inventory 2. Case 6. Folios 62-64.

${ }^{3}$ State Archive of the Republic of Tatarstan. Fund P-15. Inventory 5. Case 1844b. Folio 1; Fund R-873. Inventory 1. Case 3. Folio 1.

${ }^{4}$ State Archive of the Russian Federation. Fund R-6991. Inventory 2. Case 20. Folios 88 $89,91-95,99$.
} 
Muslims with a center in the city of Ufa, three more Muslim spiritual administrations were established in the North Caucasus (Buinaksk), Transcaucasia (Baku), Central Asia and Kazakhstan (Tashkent). The status of an informal leader was assigned to the Central Asian spiritual administration.

Finally, which is especially important in the context of this article, the switching of people's consciousness into the field of national potential nourishing in a person feelings of heroism, pride, sacrifice, was crucial for the regions in which a significant number of representatives of the non-Russian nation lived. The Tatar cultural factor, which was richly reflected in traditions, literature, and songwriting, became extremely important in the Tatar ASSR.

This factor was used in various aspects. The national idea was used by the authorities in addressing letters on behalf of the peoples of the USSR to their compatriots who fought in the army. "A letter to the Tatar front-line soldiers ..." from the working people of the Tatar ASSR [30], published in "Pravda" on March 5, 1943, received massive support: it was signed by one and a half million people [35, p. 280]. Tatar front-line newspapers of the war years helped to strengthen the moral and combat qualities of the Tatars. According to A.K. Ainutdinov, during the war there were 16 such periodicals [2], whose editors and correspondents were famous Tatarstan writers and journalists: Musa Jalil was a literary employee of the newspaper "Otvaga" (Courage), Khatib Usmanov served in the newspaper "Vatan Uchen" (For the Motherland) of the North-Western Front. Ibrahim Gazi and Adele Kutui actively collaborated with the editorial board of the newspaper "Kyzyl Armiya" (Red Army) of the First Belorussian Front. Abdrakhman Absalyamov worked in the newspaper "Vatan Uchen Sugyshka" (In battles for the Motherland) of the Karelian Front. Reading newspapers in their native language united the soldiers, cheered them up, and helped to survive.

An important event related to dramatic changes in national policy occurred on April 24, 1944, when the Order of the All-Union Committee on Higher School Affairs under the Council of People's Commissars of the USSR "On the organization of the Department of Tatar Language and Literature at Kazan State University named after V.I. Ulyanov-Lenin" was promulgated [36, p. 216]. The emergence of a new institutional education meant the expansion of the sphere of formation of the national intelligentsia. The Tatar Language and Literature Department was established in the Fall of 1944 at the Faculty of History and Philology.

Of course, wartime conditions made it difficult to solve the personnel problem, material equipment, and the selection of student contingent. The department received a very small room and a limited book fund. There was no special cabinet of the Tatar language and literature, nor visual aids. Nevertheless, on June 27, 1945, the Academic Council of the Faculty of History and Philology began to implement a wide program for student admission, lecturing on the history of the Tatar language and literature, and the research work of the department headed by Rabiga Afzalovna Khakimova ${ }^{5}$. The five-year plan of academic work included the study of the language of the works of Sh. Marjani, Musa-Akeget-Zade, the life and work of G. Tukai (R.A. Khakimova), the analysis of the dictionary of Mahmud Kashgari

\footnotetext{
${ }^{5}$ State Archive of the Republic of Tatarstan. Fund R-1337. Inventory 2. Case 29. Folio $23^{\mathrm{v}}$.
} 
(S. Bikbulatov), etc ${ }^{6}$. The foundation of the department intensified the research of such teachers as L.Z. Zalyaletdinov, V. Khangildin, Sh. Ramazanov, R. Shakirova.

However, the ideological concessions associated with the Tatar national factor were most expressed in the works of writers and artists of the Republic. While realizing the expanded opportunities, the national intelligentsia turned to those plots of the heroic past, which, despite the previous ban, were carefully preserved in the ethnic treasury. Naki Isanbet, Fatykh Khusni, Shaikhi Mannur, Sibgat Khakim, Fatikh Karim and other writers were given the opportunity to create and publish literary works without the usual wary of state security agencies. The Tatar intelligentsia "remembered" the time of the existence of the powerful medieval Tatar states of the Golden Horde and the Kazan Khanate and revived the image of Idegei, the courageous defender of the native land, and other national heroes bravely fighting against the conquerors.

In the Fall of 1941, the play "Idegei" based on the tragedy by N. Isanbet was presented on the stage of the Tatar Academic Theater. As researcher G. Arslanov notes, the performance "was supposed to charge with optimism, a great will to win" [3, p. 80-81], which was extremely relevant during the war. As early as 1940, Naki Isanbet, the Tatar writer and dramaturge, published a composite text of the Tatar epic about Idegei with his comments. He presented Idegei as a brave warrior and, in addition, noted the important contribution of the ulus of Jochi (Golden Horde) to the history and culture of the Tatar people. The epic received rave reviews. He was rated as an outstanding literary work, comparable with the Kyrgyz epos "Manas", the Karelian "Kalevala" and others.

However, when the actuality of Idegei was lost, it was this work that became one of the main targets in the struggle against "Tatar nationalism". As soon as the territory of the USSR was liberated from the Wehrmacht troops, the authorities abruptly set about "restoring order" in the country [see 27, p. 327]. In 1943-1944, entire peoples (Kalmyks, Chechens, Crimean Tatars, Ingush, Balkars, Greeks, etc.) were evicted from their places of historical dwelling. The reason for the deportations was their unfounded accusations of mass betrayal [see 4].

In relation to the Tatar people, the eviction of which seemed rather problematic (recall that Tatars belong to the dispersed-settled ethnic groups, and therefore only one fourth of the total number of Tatars in the USSR lived in the Tatar ASSR - a republic called after the titular nation [see 21, p. 249; 26, p. 11]), the line aimed at its spiritual discrimination was very clearly manifested. It found its expression in the Decree of the Central Committee of the All-Union Communist Party of Bolsheviks "On the State and Measures to Improve Mass-Political and Ideological Work in the Tatar Party Organization” promulgated on August 9, 1944.

Earlier, similar decisions of the Party Central Committee on improving ideological work were adopted in the Moldavian, Belorussian, and Ukrainian SSR [22, p. 501-504, 506-512, 524-525; 27, p. 501, 506]. January 27, 1945, works created on the basis of the Bashkir epic were negatively evaluated in the Decree of the Central Committee of the All-Union Communist Party of Bolsheviks "On the Status and Measures of Improving the Propaganda Work in the Bashkir Party Organization" [22, p. 539-543].

\footnotetext{
${ }^{6}$ State Archive of the Republic of Tatarstan. Fund R-1337. Inventory 2. Case 42. Folio 1.
} 
In the August decree (1944), the Tatar Regional Committee of the All-Union Communist Party of Bolsheviks underwent ideological execution primarily for "mistakes" allegedly made by historians and writers while creating those works that, until recently, the authorities had assessed as "patriotically correct" and objectively reflecting the history of the Tatars. The document noted: "The Tatar Regional Committee entrusted the ideological work in the field of history to the Tatar Institute of Language, Literature, and History, unsatisfactorily directed the work of writers and artists, did not sufficiently control the repertoire of art institutions, and did not organize work on the ideological and political education of the intelligentsia. As a result, serious ideological errors took place in Republic in coverage of the history of the Tatar people, as well as in Tatar literature and art" [22, p. 515].

According to the governing bodies, "nationalist mistakes" were expressed in "embellishment of the Golden Horde, ignoring its aggressive essence", "antiscientific characterization of the Golden Horde as the homeland of the Tatar people", "incorrect assessment of the feudal Idegei epic", etc. ${ }^{7}$ [31, p. 101-102].

In fact, the republican Soviet elite was accused of connivance in "sticking out" the national factor. The central government demanded restrictions on the freedom of the creative intelligentsia in matters of self-expression, a return to the communist-imperial interpretation of the history and culture of the Tatars.

Gradually, conquered positions regarding the national question systematically returned to the "Procrustean bed" of ideological schemes established earlier in the state. The main goal of the 1944 Decree was to erase from the mass consciousness the historical memory of the past powerful Tatar states and to regulate the activities of the scholarly and artistic intelligentsia. To this end, the Tatar Regional Committee of the All-Union Communist Party of Bolsheviks received a categorical prescription "to organize the scientific development of the history of Tatarstan", "to eliminate ... the shortcomings and mistakes of a nationalist character", and to draw attention exclusively to international aspects, focusing on "research and coverage of the history of the joint struggle of Russian, Tatar and other peoples of the USSR against foreign invaders ..." [20, p. 518].

A thorough discussion of the Decree of the Central Committee of the AllUnion Communist Party of Bolsheviks took place at a meeting of the Republican Party organization in September 1944. After this, a wave of sessions and meetings swept through the institutions and organizations of the Tatar ASSR.

The main blow was inflicted on the Tatar Institute of Language, Literature, and History, whose work was derogatorily criticized by the Bureau of the Tatar Regional Committee of the All-Union Communist Party of Bolsheviks on October 6,1944 . The main provisions of the August decisions of the Central Committee of the All-Union Communist Party of Bolsheviks were practically duplicated in the resolution "On Errors and Deficiencies in the Work of the Tatar Research Institute of Language, Literature and History" made following the meeting ${ }^{8}$.

The decree also formulated the main ideological principles that should be strictly followed. According to these principles, the Golden Horde was declared an

\footnotetext{
${ }^{7}$ Russian State Archive of Socio-Political History. Fund 17. Inventory 125. Case 242. Folio 139 .

${ }^{8}$ Russian State Archive of Socio-Political History. Fund 17. Inventory 125. Case 242. Folio 139 .
} 
"aggressive, predatory state" that "waged aggressive wars and robber campaigns on the lands of the Russian people and its neighbors". Accordingly, the ulus of Jochi could only be considered as a negative phenomenon. It was impossible to talk about the "conquest" or "capture" of the Kazan Khanate by the Russian state, but only about the "annexation" that contributed to the progress of Tatars, etc.

Serious personnel shifts were made in parallel with the "work on mistakes". Kh. Yarmukhametov, director of the Institute of Language, Literature, and History, was removed from his post as "unable to cope with work". Some department heads were also removed.

In 1946, an academic session was held in Moscow dedicated to the ethnogenesis of Tatars. The Bulgarian theory of the origin of the Tatar people prevailed in historical studies, despite the fact that this hypothesis was seriously questioned during the debate. To overcome the resistance of historians who disagreed with the theory of Bulgarism, the Institute of History of the USSR Academy of Sciences created a Commission to facilitate the writing of "History of Tatarstan" under the chairmanship of A.P. Kuchkin. This commission was supposed to monitor the structure and content of the "History of the Tatar Autonomous Soviet Socialist Republic" being prepared at the Institute of Language, Literature, and History [see 11].

The regional committee of the party also "revealed" the shortcomings in the study of Tatar literature [32, fol. 101-102; 48, fol. 139] and pointed out that "the 1940 periodization of the history of Tatar literature ignores the enormous progressive influence of Russian culture on the work of Tatar writers, does not reflect the negative influence of Islam on the development of Tatar culture, does not show the struggle of progressive representatives of the Tatar people (K. Nasyri, G. Tukai and others) against the religious fanaticism of the Muslim clergy"9. "Prospect of periodization of history" and "History of literature" by B. Yafarov, "Prospect of periodization of history of literature" by Kh.Kh. Khismatullin and Ja.Kh. Agishev was ranked among the works littered with harmful "nationalist sentiments" 10 .

As already noted above, the epic Idigei, which had been considered shortly before as one of the achievements of the Tatar culture, was also sharply criticized [23, p. 68]. On November 28, 1944, the Tatar Regional Committee of the All-Union Communist Party of Bolsheviks made a resolution "On the erroneous article of N. Isanbet" regarding his " $500^{\text {th }}$ anniversary of the Tatar folk epos - dastan Idegei" published before the war in the journal "Soviet ədəbiyaty" (Soviet Literature) ${ }^{11}$. In turn, a certificate from the Propaganda and Agitation Directorate of the Central Committee of the All-Union Communist Party of Bolsheviks indicated regarding the dastan Idegei that this epic should not be "put on a par with the greatest works of oral creativity of the peoples of the USSR ..." since it "glorifies the aggressive state of the Golden Horde" and Golden Horde military commanders who acted as "leaders of robber campaigns ...".

The negative characteristics of the epic had sad consequences for the development of historical studies not only in Tatarstan, but also in those regions where

${ }^{9}$ Russian State Archive of Socio-Political History. Fund 17. Inventory 125. Case 242. Folio $139^{\mathrm{v}}$.

${ }^{10}$ State Archive of the Republic of Tatarstan. Fund P-15. Inventory 5. Case 1143. Folios 51-55.

${ }^{11}$ State Archive of the Republic of Tatarstan. Fund P-15. Inventory 5. Case 1154. Folios 30-31.

${ }^{12}$ Russian State Archive of Socio-Political History. Fund 17. Inventory 125. Case 290. Folios 7-8. 
the merits of Idegei were known and revered. So, in Kazakhstan, an ideological campaign was launched against academician A.Kh. Margulan, a researcher of the folk epic. He was accused of praising Edige (the Kazakh version of Idegei's name) and idealizing the Golden Horde [see 1; 39, p. 19-20].

The ideological dictate in the field of literature was further strengthened in 1946 when decisions were made regarding the journals "Zvezda" and "Leningrad". In the Tatar Republic, the Tatarstan branch of the Main Directorate for Literature and Publishing houses gave a negative assessment to the works "Hope", "Girl from Kazan", "Duma" by Sh. Mannur, "Pillow" by G. Kashshaf, "Source of Life" by G. Zakirov, "Hole and gap" by A. Iskhak, "Ring", "Unburned heart" by F. Khusni, "Soldier" and "Beautiful words" by A. Yerikeev. The writers were accused of preaching pessimism, decadence, lack of ideology "harmful to the education of Soviet youth".

Collections of plays "Our variety" (compiled by A. Kamal) and "We choose", a sketch by A. Kamal "We met", a play by M. Amir "Bouncer", and a collection of poems by A. Yerikeyev were criticized in 1946-1947 for the "distortion of Soviet reality" and the lack of patriotism ${ }^{13}$. In 1948, one verse was removed from the poem of Gabdulla Tukai published in a collection edited by M. Gainullin. The reason for this was the censors' doubts as to which era the incorrect formulations of the "hard life" in the poem belonged to ${ }^{14}$.

Categorical prescriptions were presented to the repertoire of theaters, which required the production of modern performances "faithfully depicting the life and struggle of Soviet people"15. At the end of the 1940s, the operas "Altynchech", "Tulyak", "Zyugra" by N. Zhiganov, "Galiyabanu", "Zulkhabira" by M. Muzafarov, "Mountain Story" by A. Klyucharev, "Bashmagym" by J. Fayzi underwent an ideological crackdown. The representative of the Central Committee of the All-Union Communist Party of Bolsheviks, who checked the work of the Tatar Opera and Ballet Theater in July 1949, pointed out a number of "shortcomings" that made it possible to determine what party-state officials wanted to see on the stage of spectacular institutions. He writes condemning the lack of "ideologically and artistically complete" works of national authors in the theater's repertoire: "None of the works reveals great friendship and ties between nations. Nowhere is it said about the enormous progressive revolutionary influence of the Russian people, Russian culture. The topics related to the life of Lenin, Molotov, Kirov, Gorky in Kazan are not covered anywhere. None of the works shows the leading role of the party" ${ }^{\prime 6}$. In the late 1940s, about two dozen performances of Kazan theaters were banned from showing as inconsistent with ideological principles [15, p. 638-642].

At the same time, according to contemporaries, the hidden persecution of the great Tatar composer S. Saydashev began. In 1948, S. Saydashev, the author of the "March of the Soviet Army" (which, according to S. Shamov, ranks fifth in terms of beauty and value among the masterpieces of world music [38, p. 80]), was re-

${ }^{13}$ State Archive of the Russian Federation. Fund R-9425. Inventory 1. Case 440. Folios 45, 49; Case 545. Folio 180.

${ }^{14}$ State Archive of the Russian Federation. Fund R-9425. Inventory 1. Case 663. Folio 161.

${ }^{15}$ State Archive of the Republic of Tatarstan. Fund P-15. Inventory 30. Case 6. Folio 287.

${ }^{16}$ Russian State Archive of Socio-Political History. Fund 17. Inventory 133. Case 368. Folios 106-107. 
moved from the post of conductor and Musical Director of the Tatar Theater. In 1952, devastating articles by Z. Khayrullina and Ch. Bakhtiyarova were published under the eponymous title "About the work of Salikh Saydashev" in the journal "Sovet adəbiyaty" (Soviet Literature) [38, p. 43]. As a result of such dramatic circumstances, he became really poor and died suddenly in 1954.

Study books on humanities underwent ideological revisions. A textbook on Tatar literature for the eighth grade of middle school was sharply criticized twice (in September 1948 and in January 1952). The authors were accused of being "captured by bourgeois objectivism", including "harmful works" in the textbook, poorly illuminating the influence of Russian literature on Tatar literature, incorrectly assessing Jadidism, the role of Islam. The overall result of this campaign was that the names and works of the people who made up the pride of Tatar literature, fell into disgrace. One of the authors of the textbook, literary critic B. Yafarov, was expelled from the ranks of the All-Union Communist Party of Bolsheviks for misinterpreting the problems of its development, and M. Gainullin, director of the Institute, was reprimanded. In turn, L. Zalyay, G. Kashshaf, and G. Khalit suffered for a positive assessment of Jadidism [see 29].

Teaching materials for high school fell into the stream of criticism after school literature. In the Fall of 1950, the Department of Tatar Language and Literature of Kazan State University attracted a wide scholarly community to discuss curricula, as well as courses "Introduction to Linguistics" and "Tatar Literature for Secondary Schools"17.

In 1952, in connection with the identification of "serious errors in covering the history of Tatar literature of the pre-October period" in the eighth-grade textbook, the bureau of the Tatar Regional Committee of the All-Union Communist Party of Bolsheviks posed new tasks in the study of Tatar literature and language for literary scholars and linguists. The department was forced to both re-review curricula and programs as well as hold discussions on the problems of the history and nature of Tatar enlightenment ${ }^{18}$. New version of the textbook by M.U. Usmanov and Ja.Kh. Agishev was admitted to the publishing house only after several stages of reviewing, studying by a special commission and discussion at the regional committee $^{19}$.

The expansion of the field of ideological pressure in the humanitarian sphere led to the internal self-censorship of teachers, their attention to party directives. So, in the analysis of teaching materials on folklore, comparative grammar of the Tatar and Russian languages, R.A. Khakimova, the head of the department, pointed out the shortcomings in the "disclosure of the identity, ideology, and historical conditionality" of the Tatar national folklore and, in accordance with the guidelines laid down above, noted that "it was presented in isolation from Russian culture"20. Fierce debate ensued during the discussion of the name of the ancient period, which contained a characteristic of the culture and statehood of the Golden Horde.

${ }^{17}$ State Archive of the Republic of Tatarstan. Fund R-1337. Inventory 2. Case 6. Folio 2.

${ }^{18}$ State Archive of the Republic of Tatarstan. Fund R-1337. Inventory 2. Case 238. Folio 113.

${ }^{19}$ State Archive of the Republic of Tatarstan. Fund R-1337. Inventory 2. Case 238. Folio 10 .

${ }^{20}$ State Archive of the Republic of Tatarstan. Fund R-1337. Inventory 2. Case 166. Folios 16, 23-35. 
B.A. Yafarov, the compiler of the program, did not dare to talk about the "Golden Horde period" and proposed to call it the "Bulgarian-Kazan era" $"$. The content of the program on ancient Tatar literature caused heated debates at the next meeting. The authorship, time and place of writing the work "Nahj al-Faradis" (The Way to Paradise) also turned out to be extremely debatable ${ }^{22}$. The problems of studying such works of Tatar literature as "Chura-Batyr", the dastan "Chinggis Khan", "Sayakhatname", "Yosyf and Zuleikha" etc., also became the subjects of discussions.

Thus, the Decree of the Central Committee of the All-Union Communist Party of Bolsheviks of August 9, 1944 was aimed at both establishing strict ideological control over the spiritual life of the Tatars and Tatarstan as well as restricting the activities of writers, scholars, representatives of culture and art, limited by official dogmas.

However, the authorities' desire for total control in the cultural sphere not only did not "break" the national intelligentsia, but partly even revived the discussion over the ethnic and socio-cultural history of Tatars. This was especially noticeable during the years of the "thaw". So, despite the widespread approval of the Bulgarian theory of the origin of Tatars, the orientalist M.G. Safargaliyev did not stop his research in the study of the Golden Horde [32]. Later Sh.F. Mukhamedyarov and M.A. Usmanov also studied this subject. Limitations in the field of Tatar national literature and linguistics did not stop the study of the complex problems of the origin of the Tatar language, its history and teaching methods. Issued of the Tatar enlightenment of the nineteenth century continued to be developed in the field of the history of the Tatar people.

The creative intelligentsia did not abandon attempts to change the situation as well. G. Kashshaf, S. Battal, Sh. Mannur, Sh. Mudaris, A. Eniki, N. Fattakh, and others defended the identity of the Tatar culture. With the onset of democratic change, Tatar writers and cultural figures came up with a number of sore problems and questions: freedom of creativity, the need to improve the conditions for the development of national culture, the resumption of Tatar newspapers and magazines that appeared before the war, etc. During a meeting of the Writers' Union of the Tatar Autonomous Soviet Socialist Republic in 1957, representatives of the Tatar creative elite even tried to change the assessments of the epos "Idegei", established after the August Resolution of the Central Committee of the All-Union Communist Party of Bolsheviks in 1944, and suggested that it could be considered not a "feudal", but a "popular" one. They also suggested considering Jadidism not as a manifestation of pan-Turkism, but as a scholarly and educational popular movement. But these questions were only posed. They could not be resolved, since the liberalization of the political regime in the country ended quite quickly and the previous trends prevailed in national cultural policy.

${ }^{21}$ State Archive of the Republic of Tatarstan. Fund R-1337. Inventory 2. Case 166. Fo$\operatorname{lios} 26-27^{\mathrm{v}}$.

${ }^{22}$ According to modern scholars, Mahmud al-Bulgari wrote "Nahj al-Faradis" in the Golden Horde city of Sarai in 1357-1358. Recently it was presented to the general public [see 4; 10;24;25]. 


\section{REFERENCES}

1. Azarov A. Al'key Margulan i zhernova repressiy. Trudnye otnosheniya uchenogo s sovetskoy vlast'yu [Alkey Margulan and the millstone of repression. The scholars' difficult relationship with the Soviet regime]. Radio Azattyk. Available at: https://rus.azattyq.org /a/kazakhstan-soviet-scientist-alkey-margulan/30101609.html (Last accessed 30.08.2019). (In Russian)

2. Aynutdinov A.K. Letopis' podviga: Istoricheskiy ocherk po stranitsam frontovykh gazet [Chronicle of the Feat: A Historical Sketch on the Pages of Frontline Newspapers]. Kazan: Tatar book publishing house, 1984. 110 p. (In Russian)

3. Arslanov M.G. Tatarskoe rezhisserskoe iskusstvo (1941-1956 gg.) [Tatar Directorial Art (1941-1956)]. Kazan: Institute of Language, Literature and History, 1996. 224 p. (In Russian)

4. Bugay N.F. L. Beriya - I. Stalinu: «Soglasno vashemu ukazaniyu...» (O deportatsii narodov v SSSR v 30-40-e gg.) [Beria to I. Stalin: “According to your instructions ..." (On the deportation of peoples to the USSR in the 1930-40s)]. Moscow: AIRO-KhKh, 1995. 319 p. (In Russian)

5. V Bolgare prezentovali perevod sochineniya XIV veka «Nakhdzh al-Faradis» («Put" $v$ ray») Makhmuda al-Bulgari [A Translation of the $14^{\text {th }}$ century Work "Nahj al-Faradis" (The Way to Paradise) by Mahmud al-Bulgari Was Presented in Bolghar]. Available at: https://www.tatar-inform.ru/news/2019/06/15/654097/ (Last accessed 15.06.2019). (In Russian)

6. Galiullina D. Obsuzhdenie nekotorykh aspektov istorii tatarskogo naroda na kafedre istorii SSSR KGU vo vtoroy polovine 1940-kh gg. [Discussion of some aspects of the history of the Tatar people at the Department of History of the USSR of Kazan State University in the second half of the 1940s]. Gasyrlar avazy - Ekho vekov [The Echo of the Ages]. 2004, no. 2, pp. 26-28. (In Russian)

7. Gallyamova A.G. Istoriya Tatarstana: modernizatsiya po-sovetski (vtoraya polovina 1940-kh-pervaya polovina 1980-kh gg.) [History of Tatarstan: Soviet-style Modernization (second half of the 1940s - first half of the 1980s)]. Kazan: Magarif, 2010. 223 p. (In Russian)

8. Gallyamova A.G. Ideologiya i obshchestvenno-politicheskaya situatsiya v TASSR vo $2-y$ polovine $1940-\mathrm{kh}$ - seredine 1980-kh gg. [Ideology and socio-political situation in the Tatar Autonomous Soviet Socialist Republic in the second half of the 1940s - mid1980s]. In: Gallyamova A.G., Kabirova A.Sh., Ivanov A.A., Gaynetdinov R.B., Minnullin I.R., Almazova L.I. Istoriya Tatarstana i tatarskogo naroda. 1917-2003 gg.: ucheb. posobie [History of Tatarstan and the Tatar People. 1917-2003: Textbook]. Kazan: Kazan State University Publ., 2014, pp. 231-243. (In Russian)

9. Gallyamova A.G. «Otmechavshiesya v postanovlenii TsK VKP(b) nedostatki... do sikh por ne preodoleny» (Godu literatury posvyashchaetsya) ["The shortcomings noted in the resolution of the Central Committee of the Central Committee of the All-Union Communist Party of Bolsheviks ... have not yet been overcome" (dedicated to the year of literature)]. Ekho vekov - Gasyrlar avazy [The Echo of the Ages]. 2015, no. 1/2, pp. 84-93. (In Russian)

10. Gibadullin I.R., Sayfetdinova E.G. Makhmud al-Bulgari. Nakhdzh al-Faradis (glava III, razdel 1) [Mahmud al-Bulgari. Nahj al-Faradis (Ch. III, sect. 1)]. Zolotoordynskoe obozrenie=Golden Horde Review. 2019, vol. 7, no. 1, pp. 175-184. DOI: 10.22378/2313-6197.2019-7-1.175-184 (In Russian)

11. Zakiev M.Z. 50 let poiskov i otkrytiy [50 years of research and discoveries]. 50 let poiskov $i$ otkrytiy [50 Years of Research and Discoveries]. Kazan: Tatar book publishing house, 1989, pp. 12-20. (In Russian) 
12. Ibragimov R.R. Gosudarstvenno-konfessional'nye otnosheniya v Tatarstane $v$ 1940-1980-e gg.: dis. ... kand. ist. nauk [State-confessional Relations in Tatarstan in the 1940-1980s: PhD Thesis]. Kazan, 2004. 225 p. (In Russian)

13. Izmaylov I.L. «Ne dano marksistskoy otsenki Zolotoy Orde» [The Golden Horde has not received a Marxist assessment]. Gasyrlar avazy - Ekho vekov [The Echo of the Ages]. 1996, no. 3/4, pp. 96-101. (In Russian)

14. Izmaylov I.L. Otsenka bulgarskogo perioda $\mathrm{v}$ tatarskoy istorii: nauchnye kontseptsii i obshchestvennoe soznanie [Assessment of the Bulgarian period in Tatar history: academic concepts and public consciousness]. Natsional'naya istoriya tatar: teoretikometodologicheskoe vvedenie [National History of the Tatars: Theoretical and Methodological Introduction]. Kazan: Institute of History of Tatarstan Academy of Sciences, 2009, pp. 57-75. (In Russian)

15. Istoriya Kazani $v$ dokumentakh $i$ materialakh. XX vek [The History of Kazan in Documents and Materials. The twentieth century]. R.U. Amirkhanov (ed.). Kazan: Magarif, 2004. 711 p. (In Russian)

16. Iskhakov D.M. Nauchnaya intelligentsiya i natsional'noe samosoznanie tatar (1940-1990-e gg.) [Scholarly intelligentsia and national identity of the Tatars (the 194090s)]. Tatarskiy put': prava naroda i politkorrektnost' [The Tatar Way: The Rights of the People and Political Correctness]. Kazan: Magarif, 2003, pp. 129-136. (In Russian)

17. Iskhakov D.M. Problemy stanovleniya i transformatsii tatarskoy natsii [Problems of Formation and Transformation of the Tatar Nation]. Kazan, 1997. 247 p. (In Russian)

18. Iskhakov D.M. Rol' intelligentsii v formirovanii i sovremennom funktsionirovanii natsional'nogo samosoznaniya tatar [The role of the intelligentsia in the formation and modern functioning of the national identity of the Tatars]. Sovremennye natsional'nye protsessy $v$ Respublike Tatarstan [Modern National Processes in the Republic of Tatarstan], no. 2. Kazan: Institute of Language, Literature and History, 1994, pp. 5-26. (In Russian)

19. Kabirova A.Sh. Tatarskiy natsional'nyy faktor kak element ideologicheskoy liberalizatsii v gody Velikoy Otechestvennoy voyny [Tatar national factor as an element of ideological liberalization during the Great Patriotic War]. Tatarica. 2015, no. 4, pp. 98109. (In Russian)

20. Krivonozhkina E.G., Khanipova I.I. Sel'skoe naselenie Tatarskoy ASSR nakanune $i$ $v$ gody Velikoy Otechestvennoy voyny [The Rural Population of the Tatar Autonomous Soviet Socialist Republic on the Eve of and during the Great Patriotic War]. Kazan: Center for Innovation Technology, 2011. 464 p. (In Russian)

21. Kozlov V.I. Natsional'nosti SSSR (etnodemograficheskiy obzor) [Nationalities of the USSR (ethno-demographic review)]. Moscow: Statistics, 1975. 263 p. (In Russian)

22. Kommunisticheskaya partiya Sovetskogo Soyuza v rezolyutsiyakh i resheniyakh $s^{\prime \prime}$ ezdov, konferentsiy i plenumov TsK. 1898-1986, T. 7: 1938-1945 [The Communist Party of the Soviet Union in Resolutions and Decisions of Congresses, Conferences and Plenums of the Central Committee. 1898-1986, Vol. 7: 1938-1945]. Moscow: Political Publishing, 1985. 574 p. (In Russian)

23. Kul'turnoe stroitel'stvo v Tatarii (1941-1970): Dokumenty i materialy [Cultural Construction in Tatarstan (1941-1970): Documents and Materials]. M.K. Mukharyamov (ed.). Kazan: Tatar book publishing house, 1976. 520 p. (In Russian)

24. Mahmud al-Bulgari. Nakhdzh al-Faradis. Put' v ray. Perevod. Transkriptsiya [Nahj al-Faradis. Way to Heaven. Translation. Transcription]. Gibadullin I.R., Sayfetdinova E.G., Galiullina E.R. (tr.); Nurieva F.Sh. (transcription). Moscow: Islamic book, 2019. 320 p. (In Russian)

25. Mahmud al-Bulgari. Nakhdzh al-Faradis. Put' v ray. Faksimile [Nahj al-Faradis. Way to Heaven. Facsimile]. Mirgaleev I.M., Sayfetdinova E.G. (eds). Moscow: Islamiic book, 2019. 448 p. (In Russian) 
26. Narodnoe khozyaystvo Tatarskoy ASSR k 50-letiyu so dnya obrazovaniya: stat. sb. [National Economy of the Tatar Autonomous Soviet Socialist Republic on the Occasion of the $50^{\text {th }}$ Anniversary of the Founding. Collected papers]. G.D. Mayorov (ed.). Kazan: Statistics, 1970. 195 p. (In Russian)

27. Noveyshaya istoriya Rossii. 1914-2005 [Contemporary History of Russia. 1914-2005]. M.V. Khodyakov (ed.). Second edition. Moscow: Higher education, 2007. 525 p. (In Russian)

28. Pinaeva D.A. Interpretatsiya natsional'noy istorii i kul'tury v kontse 1940-kh nachale 1960-kh gg.: vzaimootnosheniya vlasti i intelligentsii (na materialakh Tatarskoy ASSR) [Interpretation of national history and culture in the late 1940s - early 1960s: the relationship of power and intelligentsia (based on the materials of the Tatar Autonomous Soviet Socialist Republic)]. Istoricheskie, filosofskie, politicheskie i yuridicheskie nauki, kul'turologiya i iskusstvovedenie. Voprosy teorii i praktiki [Historical, Philosophical, Political, and Legal Studies, Cultural Studies and Art History. Questions of Theory and Practice]. 2017, no. 1(75), pp. 162-167. (In Russian)

29. Piskarev V., Sultanbekov B., Gibadullina R. «Etot uchebnik ne vyderzhivaet bol'shevistskoy kritiki» ["This textbook does not stand up to Bolshevik criticism"]. Gasyrlar avazy - Ekho vekov [The Echo of the Ages]. 1997, no. 1-2, pp. 81-111. (In Russian)

30. «Pis'mo tatarskogo naroda frontovikam-tataram» i otvety na nego: sb. dok. ["Letter from the Tatar People to the Tatar Front-line Soldiers" and Answers to It]. Mustakimov I.A., Gaffarova G.V. (eds). Kazan: Main Archival Administration under the Cabinet of Ministers of the Republic of Tatarstan, 2012. 144 p. (In Russian)

31. Postanovlenie byuro Tatarskogo obkoma VKP(b) ot 6 oktyabrya 1944 g. «Ob oshibkakh i nedostatkakh v rabote Tatarskogo nauchno-issledovatel'skogo instituta yazyka, literatury $\mathrm{i}$ istorii» [Resolution of the Bureau of the Tatar Regional Committee of the AllUnion Communist Party of Bolsheviks of October 6, 1944 "On Errors and Deficiencies in the Work of the Tatar Research Institute of Language, Literature, and History"]. Gasyrlar avazy - Ekho vekov [The Echo of the Ages]. 1996, no. 3/4, pp. 101-102. (In Russian)

32. Safargaliev M. Odin iz spornykh voprosov istorii Tatarii [One of the controversial issues of the history of Tatarstan]. Voprosy istorii [Questions of History]. 1951, no. 7, pp. 74-80. (In Russian)

33. Sultanbekov B.F. «Idegey», Stalin i nashe vremya [“Idegei”, Stalin and our time]. Stranitsy sekretnykh arkhivov [Pages of Secret Archives]. Kazan: Tatar book publishing house, 1994, pp. 203-235. (In Russian)

34. Tagirov I.R. Na ideologicheskom fronte [On the ideological front]. Ocherki istorii Tatarstana $i$ tatarskogo naroda (XX vek) [Essays on the History of Tatarstan and the Tatar People (twentieth century)]. Kazan: Tatar book publishing house, 1999, pp. 335-337. (In Russian)

35. Tatariya $v$ period Velikoy Otechestvennoy voyny 1941-1945 gg.: sbornik dokumentov i materialov [Tatarstan during the Great Patriotic War of 1941-1945. Collection of Documents and Materials]. Zalyalov A.M., Smykov Yu.I, Subaev N.A. (eds). Kazan: Tatar book publishing house, 1963. 360 p. (In Russian)

36. Tumasheva D.G. Razvitie tatarskogo yazykoznaniya v Kazanskom universitete (19441995) [The development of Tatar linguistics at Kazan University (1944-1995)]. Gasyrlar avazy - Ekho vekov [The Echo of the Ages]. 1996, no. 1/2, pp. 212-216. (In Russian)

37. Khaplekhamitov R.B. Tatarskaya tvorcheskaya intelligentsiya $i$ vlast' (19441965 gg.) [Tatar Creative Intelligentsia and Power (1944-1965)]. Kazan: Word, 2011. 152 p. (In Russian)

38. Shamov S. Melodii sud'by naroda [Melodies of the Fate of the People]. Kazan: V.I. Ulyanov-Lenin Kazan State University, 2004. 154 p. (In Russian)

39. Eto ne dolzhno povtorit'sya. Stenogramma diskussii po kazakhskomu eposu (11-15 aprelya 1953 g.) [This Should Not Be Repeated. Transcript of the Discussion on the Kazakh Epic (11-15 April 1953)]. Orazaev F. (ed.). Almaty, 2007. 320 p. (In Russian) 
About the authors: Alfiya G. Gallyamova - Dr. Sci. (History), Associate Professor, Leading Research Fellow of the Department of Contemporary History, Marjani Institute of History of Tatarstan Academy of Sciences (7A, Baturin Str., Kazan 420111, Russian Federation); ORCID: 0000-0003-4344-902X. E-mail: alfiya1955@gmail.com

Aislu Sh. Kabirova - Dr. Sci. (History), Associate Professor, Leading Research Fellow of the Department of Contemporary History, Marjani Institute of History of Tatarstan Academy of Sciences (7A, Baturin Str., Kazan 420111, Russian Federation); ORCID: 0000-0002-7173-0874. E-mail: aikabirova@mail.ru

Ilnara I. Khanipova - Cand. Sci. (History), Associate Professor, Senior Research Fellow of the Department of Contemporary History, Marjani Institute of History of Tatarstan Academy of Sciences (7A, Baturin Str., Kazan 420111, Russian Federation); ORCID: 0000-0001-7585-8069. E-mail: ihanipova@mail.ru

Received January 10, 2020 Accepted for publication March 2, 2020 Published March 29, 2020

\title{
АВГУСТОВСКОЕ ПОСТАНОВЛЕНИЕ ЦК ВКП(б) 1944 ГОДА И ТАТАРСКАЯ ИНТЕЛЛИГЕНЦИЯ
}

\author{
А.Г. Галлямова ${ }^{l a}$, А.Ш. Кабирова ${ }^{l b}$, И.И. Ханипова ${ }^{l c}$ \\ ${ }^{1}$ Институт истории им. Ш. Марджани АН РТ \\ Казань, Российская Федераиия \\ aalfiya1955@gmail.com, ${ }^{b}$ aikabirova@mail.ru, ${ }^{c}$ ihanipova@mail.ru
}

Цель: проанализировать причины принятия Постановления ЦК ВКП(б) от 9 августа 1944 г. «О состоянии и мерах улучшения массово-политической и идеологической работы в Татарской партийной организации» и определить его влияние на деятельность татарской творческой и гуманитарной интеллигенции во второй половине 1940-х - начале 1950-х гг.

Материаль исследования: документальные источники из федеральных и региональных архивов, специальные научные работы.

Результаты и научная новизна: авторы считают, что принятие Постановления ЦК ВКП(б) от 9 августа 1944 г. следует рассматривать в контексте изменения всей общеполитической ситуации в стране, связанной с усилением диктата государства и уничтожением либеральных тенденций в идеологии, обозначившимся к концу Великой Отечественной войны. Возвеличение национального духа, необходимое в экстремальных для существования государства условиях, утратило свою актуальность. В стране все более явно зазвучали великодержавные настроения. Постановление играло роль «кнута» для национальной интеллигенции, но оно не остановило развитие гуманитарной мысли. Многие творческие деятели лишь внешне признавали идеологические рамки, но на деле часто выходили далеко за них, продолжая активно работать в области изучения этнической истории и культуры. 
Ключевые слова: национальная политика, советская культура, цензура, коммунистическая идеология, национальная интеллигенция, Татарская АССР, история татар, Золотая Орда, Постановление ЦК ВКП(б) от 9 августа 1944 г.

Для цитирования: Gallyamova A.G., Kabirova A.Sh., Khanipova I.I. The Decree of the Central Committee of the All-Union Communist Party of Bolsheviks in August 1944 and the Tatar Intelligentsia // Золотоордынское обозрение. 2020. Т. 8, № 1. С. 185-199. DOI: $10.22378 / 2313-6197.2020-8-1.185-199$

Сведения об авторах: Галлямова Альфия Габдульнуровна - доктор исторических наук, доцент, ведущий научный сотрудник отдела новейшей истории Института истории им. Ш. Марджани Академии наук Республики Татарстан (420111, ул. Батурина, 7А, Казань, Российская Федерация); ORCID: 0000-0003-4344-902X. E-mail: alfiya1955@gmail.com

Кабирова Айслу Шарипзяновна - доктор исторических наук, доцент, ведущий научный сотрудник отдела новейшей истории Института истории им. Ш. Марджани Академии наук Республики Татарстан (420111, ул. Батурина, 7А, Казань, Российская Федерация); ORCID: 0000-0002-7173-0874. E-mail: aikabirova@mail.ru

Ханипова Ильнара Ильдусовна - кандидат исторических наук, доцент, старший научный сотрудник отдела новейшей истории Института истории им. Ш. Марджани Академии наук Республики Татарстан (420111, ул. Батурина, 7А, Казань, Российская Федерация); ORCID: 0000-0001-7585-8069. E-mail: ihanipova@mail.ru 